\section{A Rapid Method for Determining Physical Properties of Undisturbed Substrate}

\author{
Carl E. Niedziela, Jr., and Paul V. Nelson ${ }^{2}$ \\ Department of Horticultural Science, North Carolina State University, \\ Raleigh, NC 27695-7609
}

Additional index words. air-filled porosity, bulk density, container capacity, particle density, total porosity

Abstract. A new tube method for determining physical properties in container substrates was compared to an existing system. While both offer the advantages of undisturbed substrate and measurement of properties without altering the geometry of the substrate in the container, the tube method is easier to conduct. Both methods proved equally effective for determining air-tilled porosity, container capacity, total porosity, bulk density, and particle density.

Procedures for the rapid determination of the physical properties of substrates often use specialized, mostly cylindrical containers, such as cans (Bunt, 1983; White and Mastalerz, 1966), polypropylene beakers (Waller and Harrison, 1986), and glass cylinders (Chen et al., 1988; D'Angelo and Titone, 1988). These methods did not duplicate the proportional changes in volume from top to bottom present in conventional pots. Fonteno et al. (1981) measured physical properties of cylindrical cores of substrate from the center of fallow pots, risking alteration of physical properties during sampling.

Bragg and Chambers (1988) described a procedure that accounts for pot geometry. A 1.15-liter plastic pot (height $12 \mathrm{~cm}$, top diameter $13 \mathrm{~cm}$, base diameter $9 \mathrm{~cm}$ ) was filled with substrate and submerged to the soil line in a water-filled tank. Holes in the bottom of the submerged pot were plugged before its removal from the tank. The holes were unplugged, and the drainage water was measured to determine air-filled porosity (AFP) at container capacity. Standard drying procedures could then be used to determine container capacity, total porosity, bulk density, and particle density. Water infiltration from the pot bottom is preferred over other methods, because less air is trapped in the substrate.

Received for publication 11 May 1992. Accepted for publication 17 Aug. 1992. This research was funded in part by the North Carolina Agricultural Research Service (NCARS), Raleigh, NC 27695 7643. Use of trade names in this publication does not imply endorsement by the NCARS of products named nor criticism of similar ones not mentioned. Assistance of N.C. Mingis is gratefully appreciated. The cost of publishing this paper was defrayed in part by the payment of page charges. Under postal regulations, this paper therefore must be hereby marked advertisement solely to indicate this fact.

Graduate Research Assistant. Present address: Extension Horticulture Specialist, North Carolina Extension Program, North Carolina Agricultural and Technical State Univ., Greensboro, NC 27420-1928

${ }^{2}$ Professor.
A simple alternative to plugging holes under water is to introduce water through a tube in the substrate. There are four advantages to this tube system: 1) Physical properties are measured in a pot with the appropriate dimensions; 2) substrate properties are undisturbed; 3) the need to plug holes in a submerged pot is eliminated; and 4) AFP can be determined without affecting a plant present in the pot, permitting a series of measurements in the same pot. We compared the tube method (TM) with the submersion

A 1 peat : 1 vermiculite $(\mathrm{v} / \mathrm{v})$ substrate method (SM). porosity (TP) of substrates. ${ }^{z}$ was prepared with sphagnum peat screened to a particle size of $\leq 3.2 \mathrm{~mm}$ and Terra-lite no. 3 vermiculite (Grace-Sierra, Milpitas, Calif.), and amended with $6 \mathrm{~kg}$ dolomitic limestone, $1.3 \mathrm{~kg}$ triple superphosphate, and $148 \mathrm{~g}$ Aqua-grow Granular (Aquatrols Corp. of America, Pennsauken, N.J.) per cubic meter. Standard 1.02-liter (height $12.3 \mathrm{~cm}$, top diameter $12.3 \mathrm{~cm}$, bottom diameter 8 $\mathrm{cm})$ plastic pots with four round holes on the bottom only (Lockwood Plastics, Dillen Products, Middlefield, Ohio) were used because it was important that only a few, easily sealable holes were present.

For SM, 12 pots were filled even with the top using $16.5 \mathrm{~g}$ of substrate each. The substrate was then compressed $1 \mathrm{~cm}$ below the top with a circular plywood disk $(1 \mathrm{~cm}$ thick, diameter $=12.3 \mathrm{~cm}$ ) to a final volume of $900 \mathrm{~cm}^{3}$.

For TM, one polyvinylchloride tube was placed along the inside wall of each pot that was filled with $162.0 \mathrm{~g}$ of substrate and packed as above. The smaller weight of substrate allowed for the space occupied by the tube. Each tube was $13.5 \mathrm{~cm}$ long with a 6-mm inside diameter and 13-mm outside diameter, with the bottom cut at a $45^{\circ}$ angle. The tube was spaced evenly between two holes on the bottom of the pot.

All pots were randomly arranged on a greenhouse bench; fertilized with $200 \mathrm{mg} \mathrm{N} /$ liter $(20 \mathrm{~N}-2.2 \mathrm{P}-11 \mathrm{~K})$ on days 1,3 , and 5 ; physical properties were measured on the 6th day. The SM procedure was conducted as described by Bragg and Chambers (1988),

Table 1. Equations used for the submersion (SM) and tube (TM) methods of determining the bulk density (BD), particle density (PD), air-filled porosity (AFP), container capacity (CC), and total

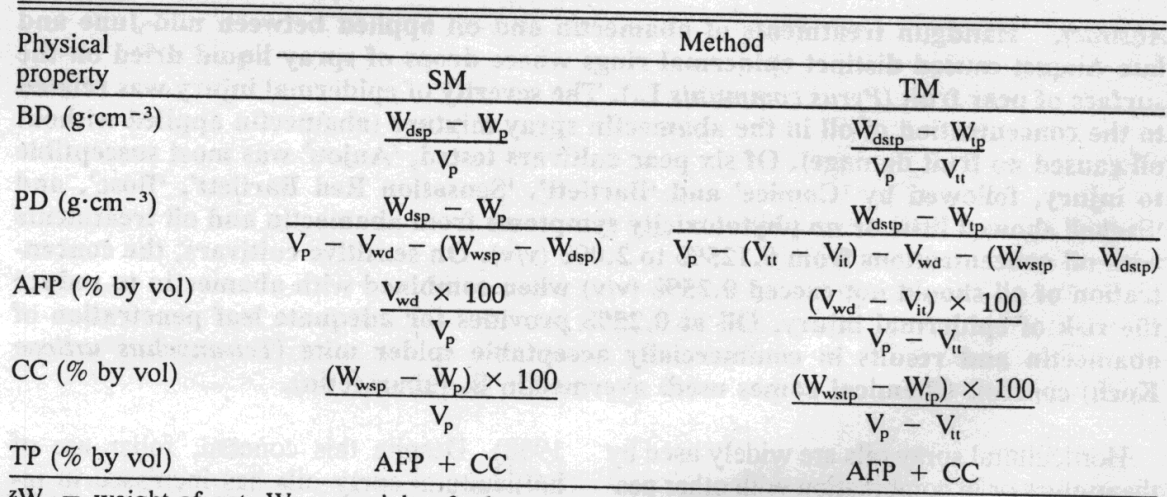

${ }^{\mathrm{z}} \mathrm{W}_{\mathrm{p}}=$ weight of pot; $\mathrm{W}_{\mathrm{tp}}=$ weight of tube + pot; $\mathrm{W}_{\text {dsp }}=$ weight of dry substrate + pot; $\mathrm{W}_{\mathrm{dstp}}=$ weight of dry substrate + tube + pot; $W_{w s p}=$ weight of wet substrate + pot; $W_{\text {wstp }}=$ weight of wet substrate + tube + pot; $V_{p}=$ volume of pot; $V_{t}=$ total volume of tube; $V_{i t}=$ volume inside tube; $V_{w d}=$ volume of water drained. Weights are in grams; volumes in cubic centimeters.

Table 2. Bulk density (BD), particle density (PD), air-filled porosity (AFP), container capacity (CC), and total porosity (TP) of a 1 peat : 1 vermiculite $(\mathrm{v} / \mathrm{v})$ substrate as determined by submersion (SM)
and tube (TM) methods.

\begin{tabular}{lccccc}
\hline \hline & \multicolumn{5}{c}{ Physical property } \\
\cline { 2 - 6 } Method & $\begin{array}{c}\text { BD } \\
\left(\mathrm{g} \cdot \mathrm{cm}^{-3}\right)\end{array}$ & $\begin{array}{c}\text { PD } \\
\left(\mathrm{g} \cdot \mathrm{cm}^{-3}\right)\end{array}$ & $\begin{array}{c}\text { AFP } \\
(\% \text { by vol })\end{array}$ & $\begin{array}{c}\text { CC } \\
(\% \text { by vol })\end{array}$ & $\begin{array}{c}\text { TP } \\
(\% \text { by vol })\end{array}$ \\
\hline SM & 0.114 & 0.770 & 10.8 & 74.3 & 85.1 \\
TM & 0.116 & 0.776 & 10.5 & 74.6 & 85.0 \\
$P<$ & 0.25 & 0.80 & 0.41 & 0.33 & 0.97 \\
\hline z & & & &
\end{tabular}


except the holes were sealed with 000 rubber stoppers. The TM pots were plugged with 000 rubber stoppers, and water was poured into the tube. Saturation was indicated for either method when the substrate surface became glossy. All pots remained saturated for $15 \mathrm{~min}$. Stoppers were removed, and drainage water was collected. After $1 \mathrm{~h}$, drainage water was measured and the pots, including substrate, were weighed. Pots and substrate were then dried at $87 \mathrm{C}$ for 1 week and reweighed. Physical properties were calculated using the equations in Table 1. Data were subjected to analysis of variance.

No significant differences were observed between the two methods for measuring substrate physical properties (Table 2). Therefore, TM is an effective alternative. Although both methods determine physical substrate properties without altering the density or geometry of the substrate in the container, TM eliminates the cumbersome process of plug- ging holes while the pot is submerged and, therefore, is easier to conduct.

However, since some components of substrate tend to float with the TM, there is a tendency to overfill the pot with water. This problem can be alleviated by adding water only until the surface of the pot begins to glisten. Although other reseachers dried substrates to $105 \mathrm{C}$ for physical property determinations (Chen et al., 1988; D'Angelo and Titone, 1988; Fonteno et al., 1981), the lower temperature (87C) was used in this comparative test to avoid distortion of the plastic pot and pipe. A separate test indicated that $1 \%$ more water was released when the higher temperature was used.

\section{Literature Cited}

Bragg, N.C. and B.J. Chambers. 1988. Interpretation and advisory applications of compost airfilled porosity (AFP) measurements. Acta Hort. 221:35-44.
Bunt, A.C. 1983. Physical properties of mixtures of peats and minerals of different particle size and bulk density for potting substrates. Acta Hort. 150:143-153.

Chen, Y., Y. Inbar, and Y. Hadar. 1988. Composted agricultural wastes as potting media for ornamental plants. Soil Sci. 145:298-303.

D’Angelo, G. and P. Titone. 1988. Determination of the water and air capacity of 25 substrates employed for the cultivation of Dieffenbachia amoeno and Euphorbia pulcherrima. Acta Hort. 221:175-182.

Fonteno, W.C., D.K. Cassel, and R.A. Larson. 1981. Physical properties of three container media and their defect on poinsettia growth. J. Amer. Soc. Hort. Sci. 106:736-741.

Waller, P.L. and A.M. Harrison. 1986. A rapid method for the assessment of air-filled porosity and its relationship with other methods. Acta Hort. 178:107-114.

White, J.W. and J.W. Mastalerz. 1966. Soil moisture as related to "container capacity." Proc. Amer. Soc. Hort. Sci. 89:758-76.5. 